\title{
EDUKASI MENGENAI SAMPAH DAN SANITASI LINGKUNGAN DI DESA CINTAMULYA, KECAMATAN JATINANGOR, KABUPATEN SUMEDANG
}

\author{
Ivan Darmawan', Muhammad Dhiyaul Haq ${ }^{2}$, dan Khairunnisa Della Egaputri ${ }^{3}$ \\ ${ }^{1,2}$ Departemen Ilmu Pemerintahan, Universitas Padjadjaran \\ ${ }^{3}$ Departemen Kesejahteraan Sosial, Universitas Padjadjaran \\ *ivan.idevice@gmail.com
}

\begin{abstract}
ABSTRAK. Kebersihan adalah sebuah nilai yang selalu ditanamkan ke dalam diri seseorang sejak kecil. Perilaku hidup dengan membudayakan hidup bersih atau sanitasi juga selalu ditanamkan dalam kehidupan bermasyarakat. Sayangnya, belum semua masyarakat dapat menerapkan pola hidup yang baik ini. Padahal sanitasi dan kebersihan lingkungan merupakan salah satu hal yang sangat penting dalam kehidupan bermasyarakat. Dengan sanitasi yang baik dan lingkungan yang bebas dari sampah akan mempengaruhi tingkat kesejahteraan masyarakat dalam suatu wilayah. Masalah sanitasi dan kebersihan lingkungan sejaitnya merupakan tanggung jawab semua pihak tanpa terkecuali, namun masih ada saja masyarakat tidak bertanggungjawab yang menyepelekan sanitasi dan masih tidak peduli akan kebersihan lingkungan. Oleh karena itu, perlu adanya edukasi kepada masyarakat mengenai pentingnya sanitasi dan menjaga kebersihan lingkungan, mulai dari contoh yang paling sederhana yaitu dengan tidak membuang sampah sembarangan. Edukasi ini diberikan melalui workshopkepada masyarakat Desa Cintamulya, Kecamatan Jatinangor, Kabupaten Sumedang, Jawa Barat dimana masyarakatnya masih kurang memiliki perhatian terhadap kebersihan lingkungan sekitar dan masih membuang sampah sembarangan seperti di selokan dan sungai secara langsung. Dari hasil survey yang dilakukan oleh tim PKM bahwasanya masih terdapat banyak sampah yang berserakan di jalan-jalan maupun di selokan sehingga menyumbat saluran air di Desa Cintamulya.Workshop dan Forum Grup Discussion (FGD) dilakukan bersama kaum ibu dan karang taruna serta tokoh setempat untuk memberikan edukasi mengenai pentingnya sanitasi dan pengelolaan sampah serta untuk membahas dan mendiskusikan secara langsung permasalahan yang dialami. Hasil dari PKM ini diharapkan masyarakat Desa Cintamulya dapat menerapkan pola hidup bersih dan menyadari pentingnya sanitasi dalam kehidupan bermasyarakat.
\end{abstract}

Kata Kunci: Sanitasi lingkungan; sampah; pengelolaan sampah

ABSTRACT. Cleanliness is a value that is always instilled in a person since childhood.Behavior of life by cultivating a clean life or sanitation is also always instilled in social life. Unfortunately, not all people can apply this good lifestyle.Even though sanitation and environmental cleanliness is one of the most important things in social life. With good sanitation and an environment free of waste will affect the level of community welfare in an area. Environmental sanitation and cleanliness issues are the responsibility of all parties without exception, but there are still irresponsible people who underestimate sanitation and still do not care about environmental cleanliness. Therefore, there is a need to educate the public about the importance of sanitation and maintaining environmental cleanliness, starting from the simplest example of not littering. This education was given through workshops to the people of Cintamulya Village, Jatinangor District, Sumedang Regency, West Java where the community still lacked attention to the cleanliness of the surrounding environment and was still littering like in ditches and rivers directly.From the results of a survey conducted by the PKM team that there is still a lot of rubbish littered in the streets and in the gutters so that it clogs waterways in Cintamulya Village.Workshop and Forum Group Discussion (FGD) was conducted with mothers and youth and local leaders to provide education on the importance of sanitation and waste management and to directly discuss and discuss problems encountered.The results of this PKM are expected by the people of Cintamulya Village to be able to apply a clean lifestyle and realize the importance of sanitation in community life.

Key words: Environmental sanitation; waste; waste management

\section{PENDAHULUAN}

Sanitasi adalah perilaku yang disengaja dalam membudidayakan hidup bersih yang bertujuan untuk menjaga dan meningkatkan kesehatan manusia. Menurut WHO, sanitasi adalah pengawasan penyediaan air minum masyarakat, pembuangan tinja dan air limbah, pembuangan sampah, vektor penyakit, kondisi perumahan, penyediaan, dan penangan makanan, kondisi atmosfer dan keselamatan lingkungan kerja.

Sanitasi lingkungan adalah status kesehatan suatu lingkungan yang mencakup perumahan, pembuangan kotoran, penyediaan air bersih dan sebagainya (Notoatmojo,2007). Sanitasi lingkungan dilakukan untuk meningkatkan dan mempertahankan standar kondisi lingkungan yang mendasar yang mempengaruhi kesejahteraan manusia. Kondisi tersebut mencakup (1) pasokan air yang bersih, (2) pembuangan limbah manusia, hewan, dan industri yang efisien, (3) perlindungan makanan dari kontaminasi biologis dan kimia, (4) udara yang bersih, (5) rumah yang bersih dan nyaman.

Lingkungan mempunyai pengaruh dan peran yang sangat besar sebagai faktor yang memengaruhi tingkat kesehatan masyarakat. Menurut Blum 
(1974) ada empat peranan lingkungan yang dapat menyebabkan gangguan kesehatan, yaitu:

1. Sebagai penyebab penyakit (agent)

Adanya mikroba penyebab penyakit seperti golongan bakteri, virus, jamur, dan protozoa, adanya zat-zat kimia, adanya radiasi, tekanan udara, aliran listrik, dan sebagainya.

2. Sebagai reservoir

Lingkungan dikatakan sebagai reservoir dapat dijelaskan dengan adanya manusia, hewan, dan benda sebagai tempat berkembangbiaknya bibit penyakit seperti sampah, air kotor, dan lainnya.

3. Sebagai vektor

Lingkungan dapat berperan sebagai penular atau penyebar penyakit, salah satunya terdapat beberapa hewan yang dapat menularkan atau memindahkan bibit penyakit seperti lalat, kecoa, nyamuk, dan lain-lain.

4. Medium transmisi

Lingkungan dapat berperan sebagai benda perant-ara agent. Contoh: air, udara, makanan dan sebagainya.

Lingkungan yang sanitasinya buruk akan menjadi sumber berbagai penyakit yang mengganggu kesehatan masyarakat. Udara yang tercemar dapat mengganggu sistem pernapasan, air minum yang terkena limbah dapat membuat sakit perut, udara yang lembab dapat menjadi tempat berkembangbiaknya bakteri dan virus yang menyebabkan penyakit. Perilaku hidup yang tidak sehat seperti membuang sampah sembarangan, tidak mencuci tangan sebelum dan sesudah makan, buang air kecil/besar sembarangan, mencuci dan mandi dengan air kotor merupakan perilkau yang mengundang berbagai penyakit.

Beberapa penyakit yang timbul disebabkan oleh sanitasi lingkungan yang kurang baik, yaitu: 1. Diare

Diare adalah sebuah penyakit yang disebabkan oleh gangguan pada organ pencernaan. Biasanya, penderita diare akan mengeluarkan fese yang lebih lembek atau cair saat sedang buang air besar. Diare dapat disebabkan karena mengkonsumsi makanan yang kurang higienis yang telah terkontaminasi bakteri atau virus. Selain itu, diare dapat disebabkan karena kebiasaan jarang mencuci tangan saat ke toilet, menyimpan makanan di tempat kurang bersih, mengkonsumsi air yang tidak bersih.

2. Demam berdarah dengue (DBD)

DBD disebabkan oleh infeksi virus dengue yang ditularkan melalui gigitan nyamuk aedes aegypti dan aedes albopictus betina yang sebelumnya telah terinfeksi virus ini sebelumnya. DBD sering terjadi di daerah tropis dengan kelembaban udara yang tinggi seperti Indonesia terurama di daerahdaerah kumuh.

\section{Disentri}

Disentriadalah penyakit infeksi saluran cerna yang ditandai dengan diare yang mengandung darah atau lendir yang biasanya terjadi selama 3-7 hari. Disentri adalah penyakit yang menular. Penyakit ini dapat disebabkan karena sanitasi lingkungan yang buruk sehingga kuman dari feses seseorang yang menderita disentri dapat menyebar. Penyebaran bakteri disentri dapat melalui makanan dan minuman yang terkontaminasi, dan melakukan kontak fisik dengan penderita disentri yang tidak mencuci tangannya.

4. Hepatitis A

Hepatitis A adalah peradangan hati yang disebabkan oleh infeksi virus. Penyakit ini dapat menular melalui konsumsi makanan atau minuman yang terkontaminasi virus hepatitis A.

Desa Cintamulya sendiri masih memiliki sanitasi lingkungan yang tergolong buruk dan kurang. Dimanamasyarakatmemilikiperilakuhidupyantidak sehat seperti masih membuang sampah sembarangan di selokan depan rumah bahkan langsung membuang ke sungai, membakar sampah, dan bahkan beberapa rumah tangga tidak mempunyai septic tank. Selain itu desa Cintamulya ini juga termasuk kawasan industri yang membuat desa ini butuh perhatian khusus dalam mengontrol pengelolaan dan pembuangan limbah sisa produksi. Masyarakat desa Cintamulya perlu tahu bahwa sanitasi yang buruk sangat mengganggu kesejahteraan hidup khususnya kesehtan manusia. Hal ini bukan hanya berdampak pada masyarakat desa Cintamulya sendiri melainkan juga masyarakat daerah-daerah yang berada satu kawasan dan satu aliran dengan sungai Citarum.

Adapun gangguan yang disebabkan oleh sampah:

1. Pencemaran lingkungan

Sampah yang dibuang sembarangan akan mencemari tanah, air, dan udara. Contohnya gas berbau busuk yang dihasilkan akan mencemari udara.

2. Sampah adalah sumber penyakit

Sampah merupakan tempat berkembangbiaknya hewan-hewan yang membantu meularkan penyakit seperti lalat, kecoa, nyamuk, tikus, dan sebagainya.

3. Sampah dapat menimbulkan kecelakaan Sampah yang berupa pecahan kaca, paku,dapat menyebabkan kecelakaan. Pembakaran sampah yang tidak diawasi menimbulkan kebakaran.

4. Sampah menimbulkan bencana

Sampah yang bertumpuk di selokan dan atau sungai menghambat aliran air sehingga pada musim hujan air akan meluap dan terjadi banjir. 
5. Sampah mengganggu pemandangan

Tumpukan sampah membuat penglihatan lingkungan sekitar tak nyaman, kotor, dan berbau tidak sedap.

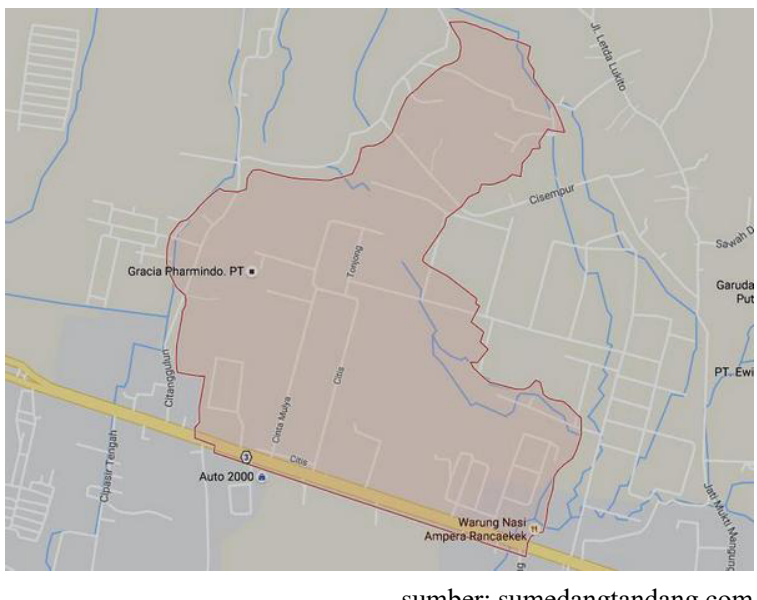

Gambar 1. Peta Wilayah Desa Cintamulya

\section{METODE}

Kegiatan ini merupakan sebuah workshop mengenai pengelolaan sampah dan sanitasi lingkungan dilakukan dengan target peserta ibu-ibu perwakilan setiap RT/RW perwakilan Karang Taruna, dan para siswa dari 3 SD di Desa Cintnamulya. Adapun Metode yang digunakan selama kegiatan workshop adalah Metode Pendekatan Partisipatif. Pendekatan Partisipatif itu sendiri merupakan metode di mana peneliti mengamati suatu fenonema dan menggalinya lebih dalam berdasarkan apa yang sedang terjadi dan berkembang dalam situasi sosial yang diteliti. Peneliti melakukan grand tour observation dan grand tour question atau bisa juga disebut sebagai penjelajahan umum, dan kemudian hasil penelitiannya bisa berupa hipotesis atau ilmu baru.

Menurut Sugiyono (2009), terdapat tiga bentuk partisipasi dalam pendekatan ini, yaitu (1) Partisipasi pasif (passive participation) di mana peneliti tidak turut aktif dalam kegiatan atau peristiwa yang diteliti, namun dia hadir dalam kegiatan atau peristiwa itu, (2) Partisipasi moderat (moderate participation), yaitu peneliti ikut aktif dalam kegiatan atau peristiwa yang diteliti, namun tidak semua kegiatan diikuti, dan (3) Partisipasi lengkap (complete participation) di mana peneliti sepenuhnya ikut andil dalam kegiatan atau peristiwa yang diteliti.

Melalui metode ini Tim melakukan observasi lapangan, dengan mengamati setiap tempat sumber perairan seperti sungai, selokkan, dan juga tempat pembuangan sampah di sekitar Desa Cinta Mulya ini. Serta memberikan output berupa penyuluhan atau workshop kepada sasaran yang menurut kami tepat untuk dilakukannya penyuluhan ini, yaitu adalah perwakilan dari ibu-ibu dan siswa-siswi SD di Cinta Mulya yaitu dilakukan di beberapa SD yaitu SDN Mekarwangi, SDN Paripurna, dan MI Muhammadiyah. Peneliti juga menerapkan bentuk partisipasi pasif di mana posisi peneliti hanya sekadar memberikan materi pengelolaan sampah dan sanitasi lingkungan. Hal ini dilakukan dengan tujuan mendorong para warga menjadi active citizen yang di mana mereka lah yang akan aktif mencari solusi dan menyelesaikan permasalahan yang ada di desanya.

\section{HASIL DAN PEMBAHASAN}

Pada Desa Cintamulya, masyarakat sekitar masih didapati belum paham betul mengenai pengolahan sampah, karena dapat dilihat dari cara mereka memperlakukan sampah rumah tangganya. Selain itu, yang menjadi masalah utama mereka dalam pengelolaan dan pembuangan sampah adalah tidak adanya Tempat Pembuangan Sementara dan Tempat Pembuangan Akhir serta jarangnya dilakukan pengangkutan sampah karena biaya pengangkutan yang mahal. Pada akhirnya, pembakaran sampah masih menjadi alternatif bagi para warga untuk menyingkirkan sampah, namun di sisi lain, pembakaran sampah pun berbahaya baik bagi lingkungan dan kesehatan.

Maka dari itu, output yang dilakukan oleh Tim adalah melakukan workshop mengenai edukasi mengenai pengolahan sampah dan sanitasi lingkungan, terutama sanitasi lingkungan terhadap air dan juga lingkungan rumah tangga kepada ibuibu agar lebih paham untuk melakukan pengolahan sampah hasil rumah tangganya, juga memberikan edukasi kepada murid SD agar terbentuk dari kecil bahagiamana cara mengolah atau membuah sampah dengan baik dan benar. Para ibu dan pewakilan Karang Taruna disuguhkan presentasi mengenai pengelolaan sampah dan sanitasi lingkungan, serta dilakukannya Forum Group Discussion untuk menemukan apa yang menjadi sumber masalah pengelolaan sampah dan sanitasi lingkungan di desa ini. Respon yang diberikann peserta terbilang positif, dan peserta cukup aktif selama diskusi. Sementara itu, dilaksanakannya lomba melukis tempat sampah dan menari bersama lewat jingle cuci tangan dari Lifebuoy.

Sebelum melakukan workshop, kami telah melakukan survey dibeberapa tempat yang terdapat sampah yang menumpuk dimana-mana dan banyak juga yang menyumbat saluran air sehingga selokkan dan sungai sekitar desa kotor dan tersumbat oleh sampah. Aliran sungai desa cisempur dan aliran sungai desa cipasir awal nya searah dengan aliran sungai yang ada di desa cintamulya tetapi semenjak adanya pabrik PT Kahatex aliran sungai tersebut 
diputuskan yang awal nya aliran sungai tersebut bersih dan melewati sawah menjadi terputus karena didirikannya pabrik kahatex tersebut yang menyebabkan aliran sungai tersebut menjadi masuk ke dalam pabrik dan di olah oleh pabrik kahatex yang sekarang di konsumsi oleh masyarakat di desa cintamulya.

\section{SIMPULAN}

Meskipun Desa Cintamulya termasuk desa yang sudah berkembang dan memiliki infrastruktur yang lebih baik dari desa lainnya, masalah kecil seperti sampah dan sanitasi lingkungan masih ada. Hal ini dikarenakan kurangnya kesadaran masyarakat mengenai sampah dan sanitasi lingkungan serta tidak adanya fasilitas yang memadai untuk membuang dan mengelola sampah dengan baik. Kendati ada warga yang menyadari masalah sampah dan sanitasi lingkungan yang terjadi, mereka atau beliau hanya mengeluh dan kurangnya inisiatif untuk menyelesaikan masalah tersebut. Menurut kamiperlu dilakukan contoh aksi nyata agar kesadaran para warga terbangun dan terdorong untuk turut menjaga kebersihan lingkungannya, dan hal ini sebetulnya dapat dilakukan oleh para tokoh masyarakat sebagai panutan atau contoh dari para warga. Para tokoh ini pun juga harus turut aktif dalam kegiatan pengelolaan sampah dan sanitasi lingkungan serta senantiasa memberikan koordinasi dan penyuluhan kepada para warga lainnya, sehingga kesadaran akan sampah dan sanitasi lingkungan meningkat dan keaktifan masyarakat dalam hal ini menjadi seimbang dan optimal.

\section{DAFTAR PUSTAKA}

Aisa, Lisa., (2018). Enviro School: Rumah Edukasi Pemanfaatan Sampah Dalam Rangka Mewrijudkan Generasi Peduli Lingkungan. Agrokreatif. 4 (1). 1-11.

Blum,H.L.(1974)Planning for Health:Development and Application of SocialChange Theory. New York: Behavioral Publications.

Darmawan, I., Mohamad Desgia, dan Bunga Billah. (2017). Pengembangan Potensi Anak-Anak Sekolah Dasar Melalui Kegiatan Pendidikan Inovatif di Desa Hegarmanah. Dharmakarya. 6(2). 99-100.

Mufidi, A Faidz. (2019). Edukasi Anak Binaan Sanggar Waringin Tentang Bullying Melalui Penyuluhan Dengan Metode Sosiodrama. Kumawula. 2 (2). 175-182.

Notoatmodjo, S. (2007). Pengantar Ilmu Kesehatan Masyarakat. Jakarta: RinekaCipta.

Sekarningrum, Bintarsih., Yogi S, dan Desi Yunita. (2020). Sosialisasi dan Edukasi Kangpisman (Kurangi, Pisahkan dan Manfaatkan Sampah). Kumawula. 3 (1). 73-86.

Sugiyono. (2009). Metode Penelitian Kuantitatif, Kualitatif dan R\&D. Bandung: Alfabeta.

Suryanto., Bambang Hermanto, dan Rusdin. (2020). Edukasi Fintech Bagi Pelaku Usaha Mikro, Kecil, dan Menengah. Kumawula. 3 (1). 1828.

Widaningsih, Lilis. Barliana, MS. (2009) Pendekatan Partisipatif dalam Metode Penelitian Arsitektur. Diambildarihttp://file.upi. edu/Direktori/FPTK/JUR._PEND._TEKNIK_ ARSITEKTUR/197110221998022LILIS WIDANINGSIH/Penelitian_Arsitektur.pd 